\title{
DAMPAK SISTEM PENGADAAN TERHADAP KESELAMATAN DAN KESEHATAN KERJA PADA PROYEK KONSTRUKSI
}

\author{
Annisa Fitria Edriani ${ }^{1}$ \\ Program Studi Teknik Sipil, Fakultas Teknik, Universitas Bengkulu \\ E-mail: annisa.fe@unib.ac.id
}

\section{Informasi Naskah: \\ Diterima: 1 April 2021 \\ Diterbitkan:}

3 Juni 2021

\begin{abstract}
Health and safety have been an ongoing issue in the construction industry. Efforts are made to create a safer working environment for the workers. However, the number of accidents, incidents and near misses in construction sites remains high. This paper aims to find a connection between procurement system and health and safety on site. To achieve this, the grounded theory method was adapted, and three procurement systems were studied. Nine stakeholders were interviewed, consisting of various stakeholders from government clients, private clients, and contractors. From the interviews, it was found that the procurement system can affect the financial, number of parties, collaboration between parties, commitment to health and safety, communication regarding health and safety, and project complexity. These factors form the project's environment then affects the implementation of health and safety in the project site.
\end{abstract}

Keyword: project procurement system, occupational health and safety, construction project

\begin{abstract}
Abstrak: Keselamatan dan kesehatan kerja (K3) telah menjadi masalah berkelanjutan dalam industri konstruksi. Upaya dilakukan untuk menciptakan lingkungan kerja yang lebih aman bagi para pekerja namun jumlah kecelakaan kerja di lokasi konstruksi tetap tinggi. Makalah ini bertujuan untuk menemukan hubungan antara sistem pengadaan dengan pelaksanaan $\mathrm{K} 3$ di lokasi proyek. Untuk mencapai ini, metode grounded theory digunakan dan tiga sistem pengadaan dipelajari. Sembilan responden diwawancarai, yang terdiri dari berbagai sektor seperti pemerintah, pemilik proyek swasta, kontraktor, dan konsultan manajemen konstruksi,. Dari hasil wawancara ditemukan bahwa sistem pengadaan dapat mempengaruhi keuangan, jumlah pihak yang terlibat, kerjasama antar pihak, komitmen pihak yang terlibat dalam proyek terhadap penerapan K3 dan kompleksitas proyek. Faktor-faktor tersebut membentuk lingkungan proyek yang kemudian mempengaruhi pelaksanaan K3 di lokasi proyek.
\end{abstract}

Kata Kunci: sistem pengadaan proyek, keselamatan dan kesehatan kerja, proyek kostruksi

\section{PENDAHULUAN}

Sektor konstruksi merupakan salah satu sektor penyumbang Gross Domestic Product (GDP) / Produk Domestik Bruto (PDB) Indonesia. Pada Triwulan IV tahun 2019, sektor konstruksi berkonstribusi sebanyak 11,26 persen terhadap Produk Domestik Bruto (PDB) Indonesia (BPS, 2020). BPS juga mendata jumlah tenaga kerja konstruksi di Indonesia mencapai 8,3 juta pekerja (Gunawan, 2020). Dengan demikian, sektor konstruksi merupakan sektor yang masif dan bersumbangsih terhadap ekonomi Indonesia. Sayangnya, angka kecelakaan kerja pada sektor konstruksi tinggi. Kecelakaan pada lokasi proyek konstruksi merupakan kejadian tidak direncanakan dan tidak diinginkan 
yang dapat terjadi dengan melibatkan pergerakan orang, benda atau bahan yang dapat mengakibatkan cedera, kerusakan atau kerugian terhadap manusia atau properti (Hosseinian dan Torghabeh, 2012). Kecelakaan dalam industri konstruksi merupakan peristiwa yang berulang dan dapat diprediksi namun terus terjadi.

Menurut Endroyo dan Tugino (2009), perencanaan keselamatan kerja konstruksi sebaiknya dilakukan jauh sebelum tahap pelaksanaan, yakni dari tahap konsepsi dan desain. Melalui Peraturan Menteri PUPR Nomor 07/PRT/M/2019 Tentang Standar dan Pedoman Pengadaan Jasa Konstruksi Melalui Penyedia, pemerintah Indonesia telah menetapkan beberapa ketentuan yang harus dipenuhi pengguna jasa dan juga penyedia jasa konstruksi. Pada rancangan anggaran dan biaya, komponen pembiayaan sistem manajemen keselamatan konstruksi (SMKK) harus dimasukkan dan apabila peserta tender tidak menyampaikan maka dinyatakan gugur (PUPR, 2019).

Dalam penelitian ini, penulis menyelidiki apakah sistem pengadaan memiliki dampak terhadap keselamatan dan kesehatan kerja (K3) di lokasi konstruksi dengan memewancari pelaku konstruksi. Fokus penelitian ini adalah sistem pengadaan design-bid-build (DBB) dan design-build (DB).

\section{TINJUAN PUSTAKA}

\section{Sistem Pengadaan Design-Bid-Build}

Di antara berbagai sistem pengadaan, sistem pengadaan (DBB) (juga dikenal sebagai sistem pengadaan tradisional) adalah salah satu yang pertama kali digunakan (Masterman, 2003). Bentuk pengadaan ini melibatkan dua pihak secara terpisah yaitu konsultan sebagai desainer dan kontraktor sebagai pembangun konstruksi. Masterman (2003) menjelaskan bahwa sistem pengadaan DBB pada umumnya menerapkan sistem pembayaran reimbursement untuk konsultan dan sistem pembayaran lump sum untuk kontraktor. Klien sebagai pemilik proyek akan menandatangani kontrak dengan konsultan dan kontraktor secara terpisah. Dalam proses desain dengan konsultan, kontraktor tidak dilibatkan (atau sedikit dilibatkan) dan hanya akan diberikan hasil desain akhir (Smith, 1999). Pengadaan ini memberikan kebebasan kepada klien untuk memilih konsultan dan kontraktor pilihan mereka secara terpisah dan untuk mengetahui biaya konstruksi sejak awal dengan asumsi tidak ada perubahan besar yang akan dilakukan pada saat konstruksi (Morledge \& Smith, 2013).

Penggunaan sistem pengadaan ini dapat menjadi tantangan ketika perubahan besar harus dilakukan pada desain karena kesulitan yang dihadapi kontraktor selama proses konstruksi. Kontraktor mungkin mengalami kesulitan untuk mengimplementasikan desain yang dibuat oleh konsultan dan perubahan ini akan menyebabkan tambahan waktu dan / atau biaya. Penelitian Osipova (2008) menemukan bahwa sebagian besar arsitek lebih menyukai penerapan design-bid-build system karena lebih fleksibel, dan arsitek lebih banyak bekerja sama dengan klien. Di sisi lain, design-bidbuild seringkali mempersulit kerja sama dengan kontraktor karena tidak dilibatkan dalam tahap produksi.

\section{Sistem Pengadaan Design-Build}

Design and build (rancang-bangun) adalah sistem pengadaan yang menggabungkan proses perancangan dan proses pembangunan menjadi satu kontrak. Sistem desain dan pembangunan memungkinkan proyek dimulai lebih cepat dan proses konstruksi lebih efektif (Davis et all, 2008). Dengan memiliki satu organisasi, umumnya kontraktor, sebagai pemegang tanggung jawab desain dan konstruksi, koordinasi terjadi secara internal tanpa melibatkan klien dan keputusan antara kontraktor dan desainer dalam kontrak dilakukan melalui kerjasama dan koordinasi (Ye et all, 2016). Menurut Levy (2006), pengadaan desain dan bangun memberikan hasil proyek yang lebih cepat dengan biaya lebih rendah daripada pengadaan desaintawaran-bangun. Penulis yang sama juga menjelaskan kekurangan dari sistem pengadaan ini: 
1. Klien yang tidak memiliki pengetahuan yang cukup dapat mengalami kesulitan dalam menyampaikan keinginan dan kebutuhannya kepada tim design and build.

2. Pengadaan ini akan menghilangkan esensi tender sehingga harga tidak kompetitif.

\section{METODOLOGI PENELITIAN}

Penulis menerapkan metode grounded theory dalam penelitian ini karena tujuan akhir dari penelitian ini adalah munculnya teori yang menjelaskan hubungan pengadaan dengan K3. Metode grounded theory adalah generasi sistematis dari teori yang diperoleh melalui data yang diperoleh secara sistematis. Penelitian ini tidak hanya melaporkan hasil data yang diperoleh tetapi menghasilkan teori yang menghubungkan konsep-konsep tersebut. Convenience sampling diterapkan dalam penelitian ini dengan menghubungi berbagai pihak dari berbagai jenjang dan jabatan organisasi. Peneliti kemudian melakukan penelitian latar belakang singkat tentang berbagai faktor seperti pengalaman, posisi saat ini, hingga calon peserta. Dengan demikian peneliti dapat menentukan data apa yang akan dikumpulkan dari siapa. Peneliti juga menerapkan metode snowball sampling dimana pada setiap akhir wawancara peneliti meminta partisipan untuk merekomendasikan rekan-rekannya yang mungkin bersedia berpartisipasi dalam penelitian ini. Sebanyak sembilan narasumber berpartisipasi dalam penelitian ini, yang terdiri dari: dua manajer K3 dari perusahaan konstruksi, satu direktur / pemilik perusahaan konstruksi, satu anggota tim keuangan perusahaan konstruksi, dua project manager, satu ahli strategi pengadaan, dan tiga konsultan K3.

Analisis data dalam penelitian ini dilakukan melalui tiga tahap yaitu open coding, selective coding, dan teoritis coding. Open coding merupakan pengolahan awal yang dilakukan terhadap data mentah yang diperoleh dari wawancara dengan partisipan.
Tujuan open coding adalah untuk melihat tema umum dari jawaban yang diberikan peserta ketika ditanya tentang implikasi pengadaan terhadap kesehatan dan keselamatan kerja di lapangan. Pada selective coding, tema-tema yang diperoleh sebelumnya diolah kembali untuk mengidentifikasi pola perilaku dan pemahaman yang lebih dalam tentang jawaban peserta pada masing-masing tema. Data yang diperoleh kemudian disusun menjadi konsep teoritis untuk mendapatkan perspektif baru tentang pengaruh sistem pengadaan terhadap K3. Proposisi ini kemudian dapat diverifikasi atau dibuktikan lebih lanjut oleh peneliti lain.

\section{HASIL PENELITIAN DAN PEMBAHASAN}

Penelitian ini menemukan bahwa sistem pengadaan tidak mempengaruhi K3 secara langsung. Namun jika ditelaah lebih dalam, setiap pengadaan memiliki karakteristik tertentu. Karakteristik inilah yang dapat berdampak pada penerapan kesehatan dan keselamatan dalam suatu proyek.

\section{Pengaruh Pengadaan Terhadap Pembiayaan K3}

Berdasarkan wawancara dengan peserta, tidak ada hubungan langsung antara sistem pengadaan dengan pembiayaan K3. Hal ini dikarenakan biaya K3 ditempatkan sebagai overhead item sehingga tidak terpengaruh oleh sistem pengadaan yang digunakan.

\section{Pengaruh Jumlah Pihak yang Terlibat dalam Pengadaan terhadap Kesehatan dan Keselamatan}

Sistem pengadaan yang digunakan mempengaruhi jumlah pihak yang terlibat dalam pengadaan. DBB memiliki tiga pihak utama: klien / pemilik, konsultan, dan kontraktor. DB hanya memiliki dua pihak besar yaitu klien dan kontraktor. Menurut stakeholders, semakin sedikit pihak yang terlibat maka pembahasan kesehatan dan keselamatan kerja menjadi lebih mudah. Klien harus memastikan bahwa kontraktor memiliki pemahaman yang sama tentang 
standar K3 yang mereka inginkan. Keterbukaan terhadap kecelakaan, insiden, dan kejadian nyaris celaka yang dialami oleh kontraktor harus dibagikan dalam rapat $\mathrm{K} 3$ untuk memastikan bahwa kecelakaan, insiden, dan kejadian nyaris celaka tidak terjadi berulang kali.

\section{Pengaruh Lain Sistem Pengadaan Terhadap Kesehatan dan Keselamatan}

\section{Kolaborasi Antar Pihak}

Kolaborasi yang baik dalam lingkungan proyek akan mempermudah penyelesaian masalah yang mungkin terjadi. Klien sebagai pemilik proyek harus bekerjasama dengan kontraktor untuk memastikan bahwa pekerja yang terlibat dalam proyek dapat bekerja tanpa membahayakan kesehatan dan diri mereka sendiri. Sistem pengadaan tertentu yang digunakan dalam suatu proyek dapat memfasilitasi kolaborasi dan sistem pengadaan yang berbeda memerlukan tingkat kolaborasi yang berbeda pula.

DBB memberikan kesempatan terbatas bagi konsultan dan kontraktor untuk dapat berkolaborasi. Hal ini terkadang menimbulkan masalah jika ada aspek desain yang memerlukan perhatian tambahan terhadap K3 karena kontraktor tidak dilibatkan dalam proses desain. Konsultan dan kontraktor di DBB harus secara sadar berupaya menjalin kerjasama satu sama lain. Hubungan kolaboratif dalam pengadaan DB umumnya terjadi lebih mudah karena, meskipun terkadang konsultan adalah perusahaan terpisah yang ditunjuk oleh kontraktor untuk mengerjakan desain, mereka bekerja sebagai satu tim.

Komitmen terhadap Kesehatan dan Keselamatan

Komitmen klien dianggap sangat penting untuk K3 di lokasi. Klien yang berkomitmen pada K3 akan menghabiskan lebih banyak waktu dengan membicarakan topik tersebut. Mereka juga tidak keberatan memilih penawar tender yang menawarkan harga sedikit lebih mahal tetapi memiliki metodologi yang lebih memperhatikan
K3. Klien dengan komitmen terhadap K3 juga tidak akan melihat anggaran K3 sebagai komponen yang sia-sia.

Komunikasi Mengenai Kesehatan dan Keselamatan

Realisasi proyek melibatkan banyak pihak sehingga membuat menginvestasikan lebih banyak waktu dan tenaga untuk memastikan bahwa semua orang berada di pemahan yang sama sangatlah penting. Pertemuan rutin antara manajer K3 dengan kontraktor utama dilakukan untuk bertukar informasi tentang risiko yang ditemukan pada pekerjaa, kecelakaan yang mereka alami, dan bagaimana mencegah atau mengatasi masalah K3 yang mereka alami. Menurut pemangku kepentingan yang diwawancarai, komunikasi tentang kesehatan dan keselamatan kerja tidak terlalu berbeda antara DB dan DBB.

Kompleksitas Proyek

Pengadaan yang berbeda digunakan untuk proyek dengan ukuran dan tingkat kompleksitas yang berbeda. Seorang pegawai pemerintah mengatakan bahwa departemennya lebih memilih DBB untuk proyek kecil sedangkan DB digunakan pada proyek besar mengingat investasi awal yang harus diinvestasikan kontraktor relatif besar. Klien lain menggunakan DBB pada proyek yang lebih besar karena mereka merasa memiliki kendali yang lebih baik atas desain jika kontrak dipisahkan antara perancang dan konstruktor. DB dan DBB pada proyek-proyek kecil sering mengabaikan K3 karena dipandang sebagai item yang berulang. Meskipun standar K3 dipertahankan, diskusi untuk meningkatkan standar K3 jarang terjadi.

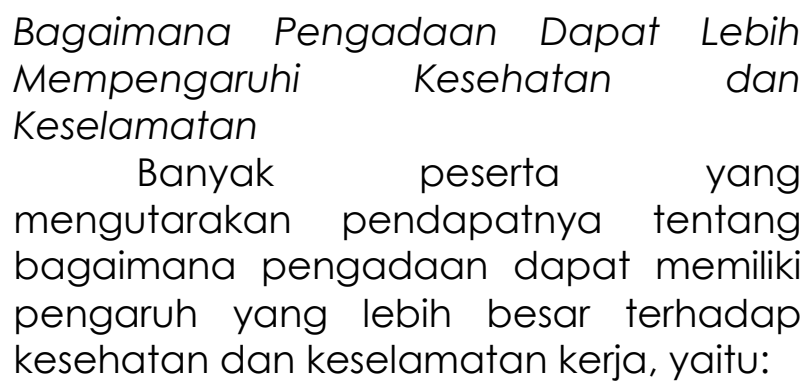

4 TEKINOSIA: Vol. 1 No. 1, bulan Juni 2021 
1. Proses seleksi harus melihat lebih dalam pada bukti penerapan K3 yang baik. Meminta kebijakan K3 tidak akan memberikan informasi yang cukup. Pemeriksaan catatan kecelakaan sebelumnya adalah penting.

2. Semua kriteria K3 harus dinyatakan di awal proses tender. Ini meminimalkan kesalahpahaman dan menghilangkan kemungkinan kontraktor / subkontraktor untuk menolak melakukan apa pun yang diminta klien terkait $\mathrm{K} 3$ dengan alasan tidak ada dalam kontrak yang disepakati.

3. Pembobotan relatif dalam proses pemilihan tender biasanya sangat berbobot pada kriteria harga. Hal ini membuat kontraktor harus sangat kompetitif dalam menetapkan harga. K3 perlu lebih diperhatikan untuk memastikan bahwa kontraktor memiliki cukup uang untuk melakukan menerapkan $\mathrm{K} 3$ dengan baik.

4. Menerapkan sistem insentif untuk K3. Untuk dapat mengajukan harga yang kompetitif, kontraktor sering kali memangkas biaya yang tidak terlihat seperti K3 Sistem intensif dilakukan dengan melakukan pembayaran terpisah untuk K3. Kontraktor akan mengusulkan jumlah dana yang dibutuhkan untuk K3 dan klien akan membayar lunas jika menganggap semua perjanjian K3 dipenuhi oleh kontraktor.

\section{KESIMPULAN}

Studi ini menemukan bahwa terdapat hubungan antara sistem pengadaan yang digunakan dengan K3 di lapangan. Hubungan tersebut terjadi secara tidak langsung dimana sistem pengadaan mempengaruhi lingkungan kerja proyek yang kemudian mempengaruhi K3. Menurut narasumber dalam penelitian ini, sistem pengadaan dapat mempengaruhi:
1. Keuangan
kesehatan
dan

keselamatan

2. Jumlah pihak yang terlibat

3. Kolaborasi Antar Para Pihak

4. Komitmen terhadap Kesehatan dan Keselamatan
5. Komunikasi Mengenai Kesehatan dan Keselamatan

6. Kompleksitas Proyek

\section{DAFTAR PUSTAKA}

Badan Pusat Statistik. 2020. Indikator Konstruksi, Triwulan IV-2019. https://www.bps.go.id/publication/ 2020/04/30/0elea759aad0ffddff2a e8a7/indikator-konstruksi-triwulaniv-2019.html. 25 Februari 2020.

Davis, R. P., Love, P., \& Baccarini, D. (2008). Building Procurement Methods.

Endroyo, B., \& Tugino, T. (2009). Analisis faktor-faktor penyebab kecelakaan kerja konstruksi. Jurnal Teknik Sipil dan Perencanaan, 9(1), pp-21.

Gunawan, A. 2020. Jumlah Pekerja Konstruksi yang Sudah \& Belum Bersertifikasi Timpang. https://ekonomi.bisnis.com/read/20 200916/45/1292638/jumlah-pekerjakonstruksi-yang-sudah-belumbersertifikasi-timpang. 20 Februari 2020.

Hosseinian, S. S., \& Torghabeh, Z. J. (2012). Major theories of construction accident causation models: A literature review. International Journal of Advances in Engineering \& Technology, 4 (2), 53.

Levy, S. (2006). Design-Build Project Delivery: Managing the Building Process from Proposal Through Construction: McGraw Hill Professional.

Masterman, J. (2003). An Introduction to Building Procurement Systems. Routledge.

Morledge, R., \& Smith, A. (2013). Building Procurement. John Wiley \& Sons.

Osipova, E. (2008). Risk Management in Construction Projects: A Comparative Study of the Different Procurement Options in Sweden (doctoral thesis). Lulea University of Technology, Luleå, Sweden.

Peraturan Menteri PUPR Nomor 07/PRT/M/2019. Standar dan Pedoman Pengadaan Jasa Konstruksi Melalui Penyedia. 25 Maret 2019. Jakarta 
Smith, N.J. (1999). Managing Risk in Construction Projects. Oxford, UK: Blackwell Science Ltd.

Yu, T., Shen, G. Q., \& Shi, Q. (2016). Comparing the Performance Quality of Design-Bid-Build and Design-Build Delivery Methods. Journal of Construction Engineering and Management, 143(4), 04016111 